\title{
Kebijakan Pemerintah Dalam Pengembangan Usaha Dive Centre oleh Pengusaha Asing di Desa Pemuteran
}

Eva April Liliyana a, 1, Ida Bagus Suryawan a, 2

1evaaprilliliyana@gmail.com,2idabagussuryawan@unud.ac.id

a Program Studi S1 Destinasi Pariwisata, Fakultas Pariwisata,Universitas Udayana, Jl. Dr. R. Goris, Denpasar, Bali 80232 Indonesia

\section{Abstract}

This article reveals about business ownership dive by tourism entrepreneurs both foreign entrepreneurs (foreign citizens) as well as local entrepreneurs (Indonesian citizen) in Pemuteran village and its licensing business. Besides, it also discusses the form of policies set by the central government and local government related to foreign entrepreneurs who set up businesses dive tourism in order to protect assets belonging to the community, especially the local businessmen in the village of Pemuteran.

Data were collecting using purposive sampling technique with qualitative descriptive in the form of a general overview of the Pemuteran village, establishment of tourism in the dive center by foreign businessmen and local businessmen in Pemuteran village and observations contained in the field notes and other explanations related to writing. These data are presented in the form of descriptions and documentation. Source of data obtained from the primary data and secondary data. Sources of primary data derived from observations to the test site and in-depth interviews. Secondary data sources such as reference books, journals and archives associated with the research. The data obtained are translated descriptively.

The results showed, the number of foreign businessmen who make an effort dive center in the Pemuteran Village more when compared with local businessmen. Therefore, government policies are needed to make the rules strict rules regarding foreign businessmen who opened the business in Pemuteran village

\section{Key Words : Policy, Dive Centre, Pemuteran Village}

\section{PENDAHULUAN}

Perkembangan kepariwisataan di Desa Pemuteran merupakan salah satu penggerak perekonomian di Kecamatan Gerokgak, Kabupaten Buleleng. Sektor pariwisata adalah sektor andalan bagi masyarakat lokal di daerah tersebut. Beberapa jenis kegiatan pariwisata yang berkembang di Desa Pemuteran adalah wisata spiritual dan wisata tirta (diving dan snorkeling), namun wisata yang paling menarik minat wisatawan adalah wisata tirta. Hal tersebut menyebabkan banyak bermunculan usaha - usaha yang menunjang keinginan wisatawan untuk dapat melakukan diving dan snorkeling seperti usaha divecentre. Akan tetapi tidak semua pemilik usaha divecentre murni berasal dari masyarakat lokal Desa Pemuteran yang notabene sebagai tuan rumah/host. Usaha divecentre yang dimiliki oleh pengusaha lokal juga tidak seluruhnya berjalan dengan baik karena adanya beberapa faktor hambatan seperti masalah modal usaha. Oleh karena itu, sebagian besar usaha divecentre yang ada di Desa Pemuteran dimiliki oleh pengusaha asing dan sebagian ada yang menggunakan investor asing dalam penanaman modal.

Pengusaha asing selaku investor merupakan mereka yang memiliki modal keuangan dalam jumlah yang besar sehingga mampu membangun sarana dan prasarana yang lebih baik ditempat yang strategis tanpa perlu khawatir terhadap biaya yang dikeluarkan. Pengusaha asing memiliki kekuatan keuangan yang besar dan sebagai investor yang ulung mereka tentu akan berpikir jangka panjang terhadap investasi mereka sekarang. Di kawasan Desa Pemuteran, pengusaha asing mendominasi lokasi - lokasi yang strategis untuk pembangunan usaha pariwisata, sedangkan masyarakat lokal hanya mampu mendirikan usahanya ditempat tempat yang kurang strategis. sehingga usaha milik pengusaha asing jauh lebih baik dari segi lokasi dan standar operasionalnya jika dibandingkan dengan usaha yang dimiliki oleh masyarakat lokal.

Melihat pergerakan investor asing di dalam penanaman modal di Bali, khususnya di daerah - daerah yang potensial sebagai jantung pariwisata maka kajian ini akan mencoba menelaah tentang "Bagaimana bentuk kebijakan pemerintah terhadap pengusaha asing di Desa Pemuteran sebagai bentuk pengamanan tehadap aset yang dimiliki oleh masyarakat lokal serta kompensasi dan kontribusi yang diberikan pengusaha asing terhadap Desa Pemuteran" merupakan salah 
satu permasalahan yang dianggap cukup menarik dan relevan untuk dikaji.

Penelitian ini dilakukan di Desa Pemuteran, Kecamatan Gerokgak, Kabupaten Buleleng dengan fokus kebijakan pemerintah terhadap pengusaha asing divecentre di Desa Pemuteran. Bagaimana bentuk pengamanan aset masyarakat lokal oleh pemerintah khususnya usaha - usaha pariwisata yang berjalan. Penentuan informan dilakukan dengan teknik purposive sampling yaitu teknik penentuan sampel dengan pertimbangan tertentu (Sugiyono, 2014). Informan yang dipilih dalam penelitian ini adalah Made Gunaksa selaku ketua pecalangsegara dan wakil ketua Yayasan Karang Sari di Desa Pemuteran, Gede Juli sebagai anggota Ikatan Pelaku Pariwisata Pemuteran (IP3), Ketut Wiasni sebagai pelayanan jasa perijinan pengusaha di Desa Pemuteran, dan para staf pengusaha asing di beberapa divecentre seperti Werner Lau, Bali Dive Academy, Plongee Divecentre, Bali Indo Divecentre.

Jenis data yang digunakan dalam penelitian ini adalah data kualitatif berupa gambaran umum Desa Pemuteran, bentuk usaha pariwisata dalam dive centre oleh pengusaha asing maupun pengusaha lokal di Desa Pemuteran dan hasil observasi yang dituangkan dalam catatan lapangan dan penjelasanpenjelasan lain yang terkait dengan penulisan. Data ini disajikan dalam bentuk uraian dan dokumentasi. Sumber data didapat dari data primer dan data sekunder. Sumber data primer berasal dari hasil pengamatan langung ke lokasi penelitian dan hasil wawancara mendalam. Sumber data sekunder berupa referensi bukubuku, jurnal dan arsip terkait dengan penelitian. Data-data yang diperoleh dijabarkan secara deskriptif.

\section{HASIL DAN PEMBAHASAN}

Peraturan mengenai pariwisata tidak hanya dikeluarkan oleh pemerintah pusat namun juga oleh pemerintah daerah, hal ini dikarenakan Negara Indonesia dalam menyelenggarakan pemerintahannya telah menjatuhkan pilihan pada Asas Desentralisasi seperti yang secara jelas terlihat dalam ketentuan Undang-Undang Dasar Negara Kesatuan Republik Indonesia Tahun 1945 beserta penjelasannya. Dianutnya sistem ini dalam penyelenggaraan pemerintahan negara didasarkan pada prinsip pemecahan kekuasaan "dispersion of power" yang bertujuan untuk mencapai efektivitas dalam penyelenggaraan pemerintahan dan guna mengembangkan demokrasi. Sejalan dengan penyerahan urusan, apabila urusan tersebut akan menjadi beban daerah, maka akan dilaksanakan melalui asas medebewind atau asas pembantuan. Desentralisasi berasal dari bahasa latin yakni (de yang berarti lepas dan Centrum yang berarti pusat).

Tujuan dari adanya desentralisasi pada bidang pariwisata adalah karena kekuasaan pusat menyadari semakin sulit untuk mengendalikan sebuah negara secara penuh dan efektif, bahwa pembangunan pariwisata adalah suatu proses yang kompleks dan penuh ketidakpastian yang tidak mudah dikendalikan dan direncanakan dari pusat. Sehingga kebijakan untuk mengatur mengenai pembangunan pariwisata juga dilakukan oleh pemerintah daerah karena pemerintah daerah lebih mengetahui tentang kebijakan yang tepat untuk di daerahnya sendiri.

Menurut anggota Ikatan Pelaku Pariwisata Pemuteran (IP3), pengusaha lokal yang membangun usaha Dive centre di Desa Pemuteran lebih mendominasi dibandingkan dengan pengusaha asing. Jika di persentasikan, pengusaha lokal $75 \%$ dan pengusaha asing $25 \%$. Berikut adalah tabel daftar nama dan pemilik perusahaan Dive centreyang ada di Desa Pemuteran. 
Tabel 1. Daftar Nama dan Pemilik perusahaan Dive centre

\begin{tabular}{|c|c|c|}
\hline No. & $\begin{array}{l}\text { Nama Perusahaan } \\
\text { Dive centre }\end{array}$ & $\begin{array}{l}\text { Pemilik Perusahaan } \\
\text { Dive centre }\end{array}$ \\
\hline 1 & $\begin{array}{l}\text { Pemuteran Dive } \\
\text { centre }\end{array}$ & $\begin{array}{l}\text { a. Gede Juli } \\
\text { b. Hermann }\end{array}$ \\
\hline 2 & $\begin{array}{l}\text { PT Bali Sunrise } \\
\text { Dive centre }\end{array}$ & Dewa Made Japa, SE \\
\hline 3 & Dive Concepts Bali & Pengusaha Asing \\
\hline 4 & Bali Dive Academy & $\begin{array}{l}\text { Pengusaha Asing } \\
\text { dari Australia }\end{array}$ \\
\hline 5 & Dive Kokak, & Pengusaha Asing \\
\hline 6 & $\begin{array}{l}\text { Reef Seen Divers } \\
\text { Resort Bali }\end{array}$ & Pengusaha Asing \\
\hline 7 & $\begin{array}{l}\text { Sea Rovers Dive } \\
\text { Pemuteran }\end{array}$ & Pengusaha Asing \\
\hline 8 & Macro Bali Dive & Putu Sudarimbawa \\
\hline 9 & $\begin{array}{l}\text { Werner Lau Dive } \\
\text { centre }\end{array}$ & Werner Lau \\
\hline 10 & Diving Indo & $\begin{array}{l}\text { Mario (WNA } \\
\text { Polandia) dan Ike } \\
\text { (WNI) }\end{array}$ \\
\hline 11 & $\begin{array}{l}\text { Mai Mondok Guest } \\
\text { House (Snorkling) }\end{array}$ & Pengusaha Lokal. \\
\hline 12 & $\begin{array}{l}\text { Fun \& Fun } \\
\text { Adventure Dive } \\
\text { centre }\end{array}$ & Pengusaha Asing \\
\hline 13 & $\begin{array}{l}\text { Kelompok Karang } \\
\text { Asri. }\end{array}$ & $\begin{array}{l}\text { Program Pemerintah } \\
\text { (PNPM) Program } \\
\text { Nasional } \\
\text { Pemberdayaan } \\
\text { Masyarakat Mandiri) }\end{array}$ \\
\hline 14 & Kubuku Dive centre & Pengusaha Lokal \\
\hline 15 & Global DiveCentre & Pengusaha Asing \\
\hline 16 & Easy Divers Centre & Pengusaha Asing \\
\hline
\end{tabular}

Sumber: Hasil Observasi, 2015

Dari tabel 1 menunjukan bahwa pengusaha asing lebih banyak memiliki usaha divecentre di Desa Pemuteran, kabupaten Buleleng. Pengusaha asing banyak memanfaatkan peluang untuk membuat usaha di Desa Pemuteran. Dari total 16 usaha dive centre yang ada di Desa Pemuteran, pengusaha lokal memiliki sebanyak 6 usaha dive centre dan pengusaha asing sebanyak 10 usaha dive centre. Namun dengan ketentuan pengusaha asing tersebut harus memberdayakan masyarakat lokal sebagai tenaga kerja yaitu sebesar $75 \%$.

Pengusaha asing di dalam usaha wisata tirta khususnya divecentre memiliki 2 kedudukan yaitu sebagai pemilik dive centre dan meminjam nama pengusaha lokal (nominee). Yang dimaksud meminjam nama adalah pengusaha asing yang berstatus sebagai pemilik sesungguhnya namun didalam sisi hukum pengusaha asing diposisikan sebagi penanam modal atau investor.

Sebagian besar pengusaha asing memanfaatkan pengusaha lokal dengan meminjam nama agar bisa memiliki sebuah usaha tanpa harus mengurus perijinan yang berbelit - belit, dan meminimalisir hambatan yang ada, mereka nampak seperti investor di permukaan. Apabila menelisik dari aturan hukum mengenai usaha pariwisata, sesuai dengan Undang - Undang No 1 Tahun 1967 tentang Penanaman Modal Asing pasal 24. Maksud dari pasal ini adalah mencegah dana atau keuntungan dari investasi lari ke luar negeri, Indonesia menginginkan agar hasil investasi diputar kembali di Indonesia atau diinvestasikan kembali di Indonesia untuk menunjang perekonomian Indonesia.

Pengusaha asing diberikan kebebasan untuk mendirikan usaha pariwisata dengan bentuk badan hukum yang harus berupa Perseroan Terbatas (PT) sesuai dengan peraturan Undang-Undang No. 25 Tahun 2007 tentang Penanaman Modal.

Undang-Undang Nomor 25 Tahun 2007 menjabarkan dengan rinci tentang kepemilikan pengusaha asing di dalam usaha jasa pariwisata di sebuah daya tarik wisata, tetapi di dalam sistem peminjaman nama WNI dalam pengatas nama sebuah usaha pariwisata seperti divecentre masih belum diatur di dalam aturan perundang-undangan di Indonesia dan hal ini dinyatakan dengan adanya kekosongan norma di dalam sistem perundang-undangan Indonesia. Apabila terjadi permasalahan dikemudian hari dari dampak negatif sebuah perjanjian pinjam nama yang dilakukan pengusaha asing dengan meminjam nama pengusaha lokal maka yang bertanggungjawab penuh terhadap usaha jasa pariwisata tersebut adalah pengusaha lokal. Pengusaha asing secara otomatis terbebas dari permasalahan tersebut. Legalnya sebuah perjanjian pinjam nama masih ditinjau keabsahannya. Hal inilah yang memerlukan sebuah kebijakan di dalam kebijakan pemerintah untuk mengisi kekosongan norma dalam kekosongan peraturan perundang-undangan untuk melindungi pengusaha lokal atau WNI yang dipinjam namanya. Mengingat sekarang ini yang menjadi korban adalah pengusaha lokal ketika terjadinya masalah. 
Adil dan merata merupakan salah satu dari asas-asas kepariwisataan yang dianut dalam Undang-UndangNo.10 Tahun 2009 tentang Kepariwisataan. Hal ini membuktikan bahwa asas ini masuk kedalam kebijakankebijakan dan aturan-aturan yang dibuat oleh pemerintah untuk kepentingan warga Negara itu sendiri. Aturan yang telah dibuat khususnya dalam lingkup tentang penanaman modal asing maupun penanaman modal nasional sudah berlaku adil dan merata, namun di kenyataannya yang belum teraplikasikan untuk rata dan adil. Masih banyak masalah-masalah penanaman modal asing di Desa Pemuteran ini yang tidak sesuai dengan peraturan yang ada.

\section{SIMPULAN DAN SARAN}

\subsection{Simpulan}

Usaha dive centre bermula dari kondisi rusaknya biota alam bawah laut pada tahun 1990 yang disebabkan oleh pencarian ikan dengan cara pengeboman. Kemudian masyarakat berupaya melakukan pelestarian terumbu karang dengan membentuk Yayasan Karang Lestari melalui teknologi biorock untuk pemulihan terumbu karang. Setelah itu, pada tahun 2004 banyak bermunculan usaha - usaha pariwisata seperti dive centre yang dimiliki oleh pengusaha lokal maupun pengusaha asing. Saat ini, jumlah pengusaha asing yang membuat usaha dive centre di Desa Pemuteran lebih banyak jika dibandingkan dengan pengusaha lokal. Oleh karena itu, diperlukan kebijakan pemerintah dengan membuat aturan - aturan yang tegas mengenai pengusaha asing yang membuka usaha di desa Pemuteran.

\subsection{Saran}

Saran yang dapat disampaikan disini terkait usaha dive centre adalah pemerintah seharusnya membuat kebijakan yang secara tegas mengatur tentang pengusaha asing. Mengingat aturan hukum yang sudah ada masih belum mampu melindungi keberadaan pengusaha lokal.

\section{DAFTAR PUSTAKA}

Budi Winarno. 2002. Teori dan Proses Kebijakan Publik. Yogyakarta : Penerbit Media Pressindo.

Kusmayadi dan Endar Sugiarto. 2000. Metodologi Penelitian dalam Bidang Kepariwisataan. Jakarta: PT. Gramedia Pustaka
Moleong, Lexy J. 2009. Metode Penelitian Kualitatif. Bandung: PT. Remaja Rosdakarya

Pasha, Mustafa Kamal dkk. 2003. Pancasila dalam Tinjauan Historis dan Filosifi. Yogyakarta :Citra Karsa Mandiri

Soekadijo. 2000. Anatomi Pariwisata. Jakarta : Gramedia

Sugiyono. 2014. Metode Penelitian Kuantitatif, Kualitatif dan R\&D. Bandung : Penerbit Alfabeta

Undang - Undang Dasar Negara Kesatuan Indonesia Tahun 1945

Undang-Undang Republik Indonesia No 1 Tahun 1967 tentang Penanaman Modal Asing (Lembaran Negara Republik Indonesia Tahun 1967)

Undang-Undang Republik Indonesia No 25 Tahun 2007 tentang Penanaman Modal (Lembaran Negara Republik Indonesia Tahun 2007 Nomor 4724)

Undang-Undang Republik Indonesia No 10 Tahun 2009 Tentang Kepariwisataan (Lembaran Negara Republik Indonesia Tahun 2009 Nomor 11)

Undang-Undang Republik Indonesia No. 23 Tahun 2014 Tentang Pemerintahan Daerah (Lembaran Negara Republik Indonesia Tahun 2014)

Peraturan Pemerintah No. 38 Tahun 2007 tentang Pembagian Urusan Pemerintah Antara Pemerintah, Pemerintahan Daerah Provinsi, dan Pemerintahan Daerah Kabupaten / Kota(Lembaran Negara Republik 